\title{
The Need for Savanna Restoration in the Cross Timbers
}

\section{Caleb Stotts}

Restoration Technician

Tallgrass Restoration

and Management, Lawrence, KS

\author{
Michael W. Palmer \\ Botany Department \\ Oklahoma State University \\ Stillwater, OK
}

\author{
Kelly Kindscher \\ Kansas Biological Survey \\ University of Kansas \\ Lawrence, KS
}

Along the prairie/forest transition zone oak savannas have been severely degraded by logging, clearing for agriculture, fire suppression, invasion of exotic plants, and excessive livestock grazing. Savanna shares equal billing with tallgrass prairie as the most threatened plant community in the Midwest. As such, there is increasing interest in restoring these communities. Conservation criteria have not been developed for the post oak (Querces stellata) and blackjack oak (Querces marilandica) savanna of the Cross Timbers. Oak savanna was arguably an important component of the historical Cross Timbers region. Following settlement, overgrazing in conjunction with a decrease in fire frequency and/or intensity has increased the density of oak stands to the point where they resemble closed-canopy forests rather than savanna. This is a threat to the biodiversity of the Cross Timbers. Proactive land management practices are recommended for restoring savanna communities. Such efforts may require thinning-out areas of degraded oak savanna to help re-establish the herbaceous understory. Fire is recommended to restore ecological processes that limit woody plant encroachment and promote biodiversity. Further research should investigate the ecological dynamics and functions of oak savannas, as well as provide further guidelines for its conservation.

\section{INTRODUCTION}

Along the prairie/forest transition zone, oak savanna communities have been severely degraded by logging, clearing for agriculture, fire suppression, invasion of exotic plants, and excessive livestock grazing (Abrams 1992). Oak savanna shares equal billing with tallgrass prairie as the most threatened plant community in the Midwest and among the most threatened in the world (Henderson 1995). As such, there is increasing interest in restoring these communities (Whitney and Decant 2005). In the Cross Timbers region, however, there has been little effort to evaluate the conservation status of savannas or woodlands.

\section{COMMUNITY CLASSIFICATION}

In the prairie/forest transition zone, upland communities are not always discrete entities separated by sharp lines. Instead, they often blend into each other imperceptibly. Even so, named communities are useful abstractions that help us think and communicate about various parts of the landscape (Palmer and White 1994, Packard and Mutel 1997). Definitions adapted from Faber-Langendeon (2001) and Lauver et al. (1999) provide us with an operational classification for common Midwestern upland communities: 1) prairie - areas dominated by herbaceous vegetation (grass and forbs); trees generally not exceeding 10\% cover; 2) savanna - areas dominated with herbaceous vegetation and scattered trees with 10-25\% cover; 3) woodland areas dominated by an open stand of trees with $25-60 \%$ canopy cover and a herbaceous understory; and 4) forest areas dominated by trees with $60-100 \%$ cover and little herbaceous vegetation. These communities are illustrated in Fig. 1.

Savanna is maintained by frequent fire. Along the prairie-forest transition zone, certain species of oaks are the only trees that were historically savanna. This is in a large part due to their physiological adaptations to fire, which include thick bark, prolific resprouting and resistance to rotting after scarring (Abrams 1992).

Stotts, et al.

https://doi.org/10.22488/okstate.17.100055 
Oklahoma Native Plant Record

Volume 7, Number 1, December 2007

Just what the understory and ground layer vegetation of oak savanna was like historically is largely unknown (Henderson 1995). While no plant species is known to be endemic to oak savanna (Nuzzo 1985), there are species that are considered savanna specialists in the Midwest (Packard 1988). Historically, the savanna community was probably a slowly shifting mosaic of plant species associations that had varying degrees of shade and sun tolerance (Henderson 1995).

\section{CROSS TIMBERS SAVANNAS}

The Cross Timbers region is located in portions of Oklahoma, Texas, Kansas, and Arkansas (Fig. 2). It is characterized by a mosaic of upland communities including prairie, savanna, woodland and forest (Fig. 3). Post oak (Quercus stellata) and blackjack oak (Quercus marilandica) are the dominant tree species throughout in the wooded systems.

Kuchler (1964) defined the potential natural vegetation of the Cross Timbers as savanna-like, characterized by tallgrass prairie with low broadleaf deciduous trees scattered singly or in groves of varying size. These groves often occur with an open canopy cover and grassy understory (Kuchler 1974). The herbaceous understory of Cross Timbers savanna is similar in composition to the surrounding prairie (Dyksterhuis 1948; Kuchler 1964, 1974, Palmer unpublished data).

Savanna also occurs in the Cross Timbers region as a gradual transition between closed-canopy forests and grasslands, with a margin of isolated trees (Dyksterhuis 1957, Penfound 1962). This sort of edge can be tens of meters wide. Classifying some Cross Timbers sites as savanna can be problematic due to the tendency of post oak and blackjack oak to root sprout and produce groupings of trees with interlocking crowns (Hoagland et al. 1999).
In the Cross Timbers region, woodlands have a similar species composition as savanna (Palmer, unpublished data). As such, we recognize that many properties of savanna are likely to be shared with woodlands, and we treat the two as largely synonymous in this paper.

\section{RESTORATION OF MIDWEST OAK SAVANNAS}

Nuzzo (1985) estimated that oak savannas in eight states in the Midwest probably covered 11 to 13 million hectares at the time of settlement and have been reduced in extent by $99.98 \%$. Packard (1988) found that several plants that were historically associated with savanna communities are now uncommon. Populations of these 'savanna specialists' have been successfully established through restoration efforts.

Largely because of these findings, the conservation value of savanna communities has been recognized and restoration efforts are increasing. The ultimate goal is to help replace the loss of habitat that is leading to the gradual disappearance of plant and animal species (Packard 1988).

\section{MIDWEST OAK SAVANNA VS. CROSS TIMBERS SAVANNA}

The Cross Timbers and certain areas of the Midwest occupy a transition zone between the Great Plains and the Eastern Deciduous forest. Despite this, the savannas of the Cross Timbers are considered distinct from Midwest Oak savannas to their north. (McPherson 1997). The Midwest is characterized by its former glaciation, relatively mesic soils and northern plant affinities, while the Cross Timbers region is characterized by its largely sandy soils, generally rough topography and southern plant affinities. Furthermore, the Cross Timbers has not experienced the extent of sod-busting that the Midwest has, and 
includes substantial areas of native tallgrass prairie and old-growth forest.

Despite these distinctions, there is very little difference in ecosystem classification. Küchler (1964) described regions of oak savanna in the Midwest as being nearly identical to that of the Cross Timbers in vegetation type; characterized by tallgrass prairie with broadleaf deciduous trees scattered singly or in groves.

\section{HISTORICAL AND CURRENT EXTENT OF CROSS TIMBERS SAVANNA}

The extent to which we can understand the structure of pre-settlement vegetation is limited. Despite this, analysis of historical accounts, early photographs, early land surveys, and existing vegetation have provided much insight into historical vegetation. Numerous authors have described historical vegetation communities throughout the Cross Timbers region as savanna-like (Bruner 1931, Dyksterhuis 1957, 1948, Lathrop 1958, Rice and Penfound 1959, Penfound 1962, Kuchler 1974, 1964, Johnson and Risser 1975, Smiens and Diamond 1986, Hoagland et al. 1999, Francaviglia 2000). This is not to conclude that savanna was the dominant vegetation type in the Cross Timbers. It does indicate, however, that savanna was a well-represented component within a mosaic of prairie and forest during the time of settlement.

Many authors conclude that, during post-settlement, overgrazing in conjunction with a decrease in fire frequency and / or intensity has increased the density of oak stands to the point where they resemble closed-canopy forests rather than savanna (Dyksterhuis 1948, 1957, Lathrop 1958, Rice and Penfound 1959, Penfound 1962, Bell and Hulbert 1974, Johnson and Risser 1975, Smiens and Diamond 1986, Abrams 1992, Hoagland et al. 1999). This conversion has been at the expense of the herbaceous understory and the associated biodiversity.

Unlike the Midwest Oak savannas, there are no reliable estimates as to how much Cross Timbers savanna actually existed at the time of settlement or how much has been lost since settlement. Despite this, these studies indicate that savannas were important aspects of the historical Cross Timbers region and now represent only a remnant of a vast vegetation type.

\section{BIODIVERSITY AND NATURAL HERITAGE}

The mosaic of communities in the Cross Timbers provide for a wide variety of habitat for plants and animals (Costello 1969, Oklahoma Biodiversity Plan 1993), and savannas contribute to this habitat diversity (Fig. 4). Savannas may produce an edge effect, where interfaces between community types support species from both communities, resulting in elevated species composition. As in the Midwest, there may be savanna specialists in the Cross Timbers, species that prefer the distinct habitat offered by an open stand of trees. Cross Timbers savanna should be valued in regards to their conservation status for their contribution to the natural heritage of the United States. This is especially true for post oak trees that have reached the age of 200+ years (Fig. 5).

According to the Oklahoma Biodiversity Plan (1993), foremost among the threats to plant diversity in Oklahoma is a dramatic change in the fire regime from what occurred historically. As the result of an altered fire regime, the encroachment of woody species into savannas is indeed a threat to the diversity of the Cross Timbers (Rice and Penfound 1959, Johnson and Risser 1975, Johnson 1986, Archer 1995, Hoagland et al. 1999). 
Oklahoma Native Plant Record

Volume 7, Number 1, December 2007

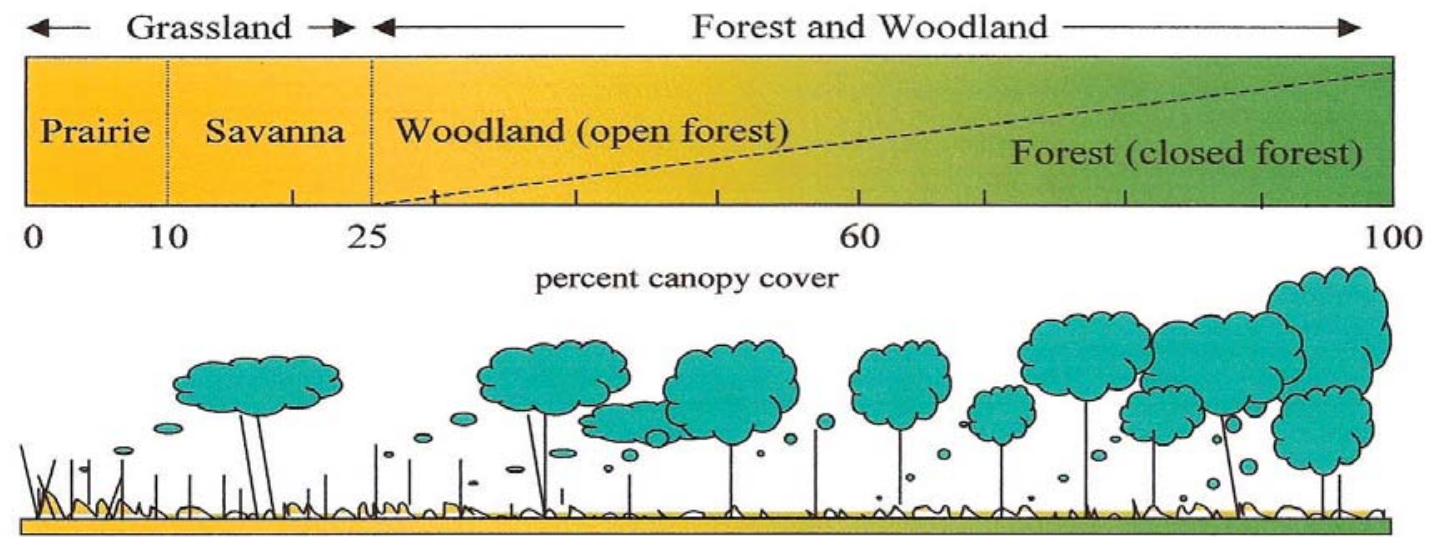

Figure 1 Schematic diagram showing the changes in structure along a gradient from prairie to forest. This structural gradient is often reflective of a fire frequency gradient, with prairies maintained by more frequent fires (Faber-Langendeon 2001).

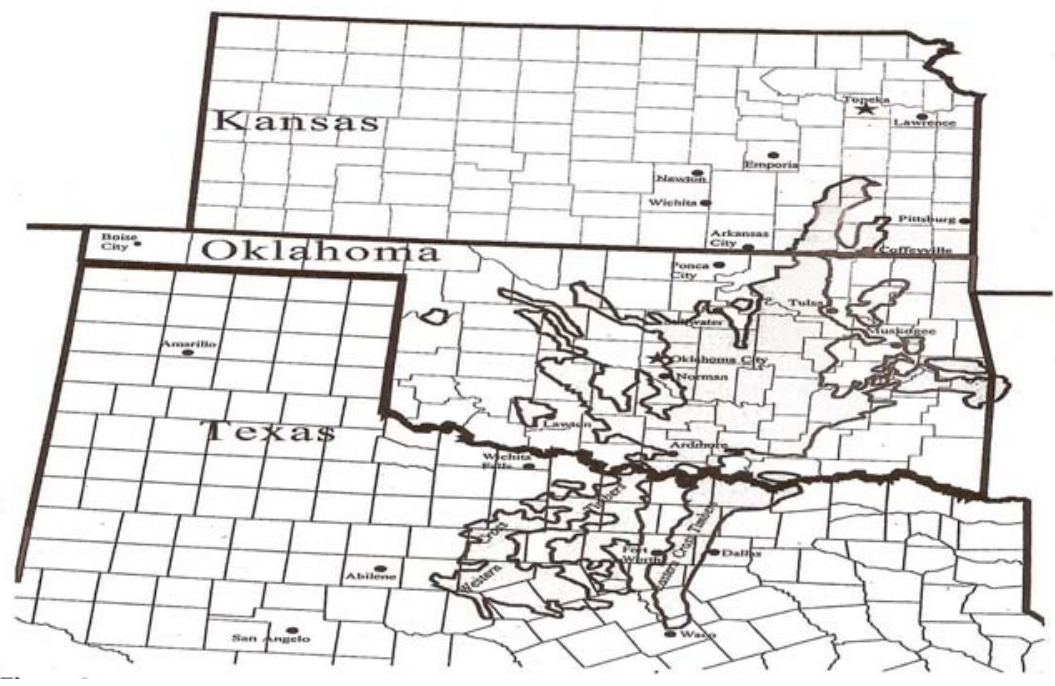

Figure 2 Location of the Cross Timbers region. (Adapted from Küchler 1964).

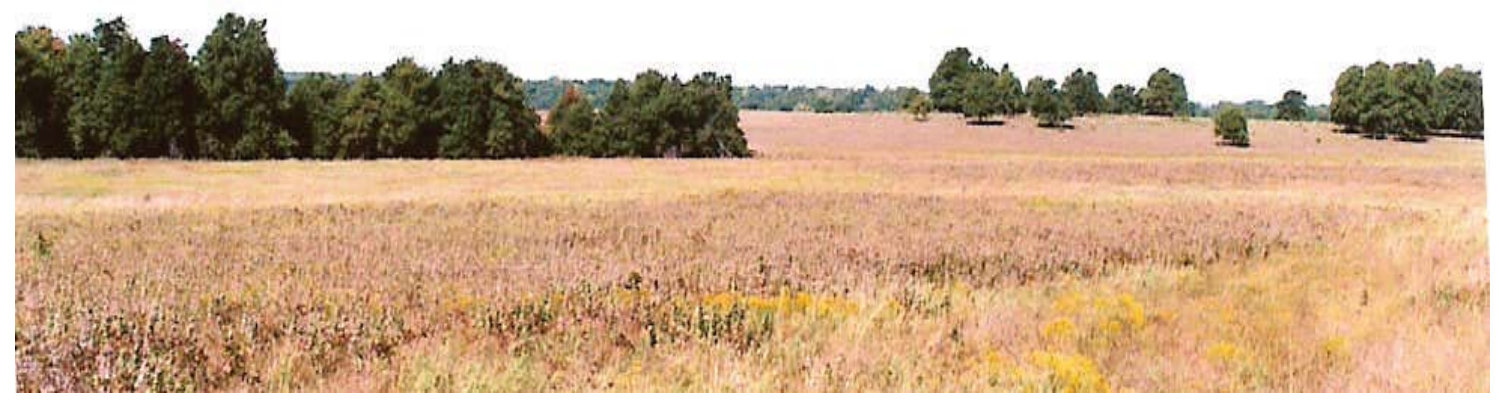

Figure 3 A Cross Timbers mosaic of prairie, savanna and forest communities.

Stotts et al. 


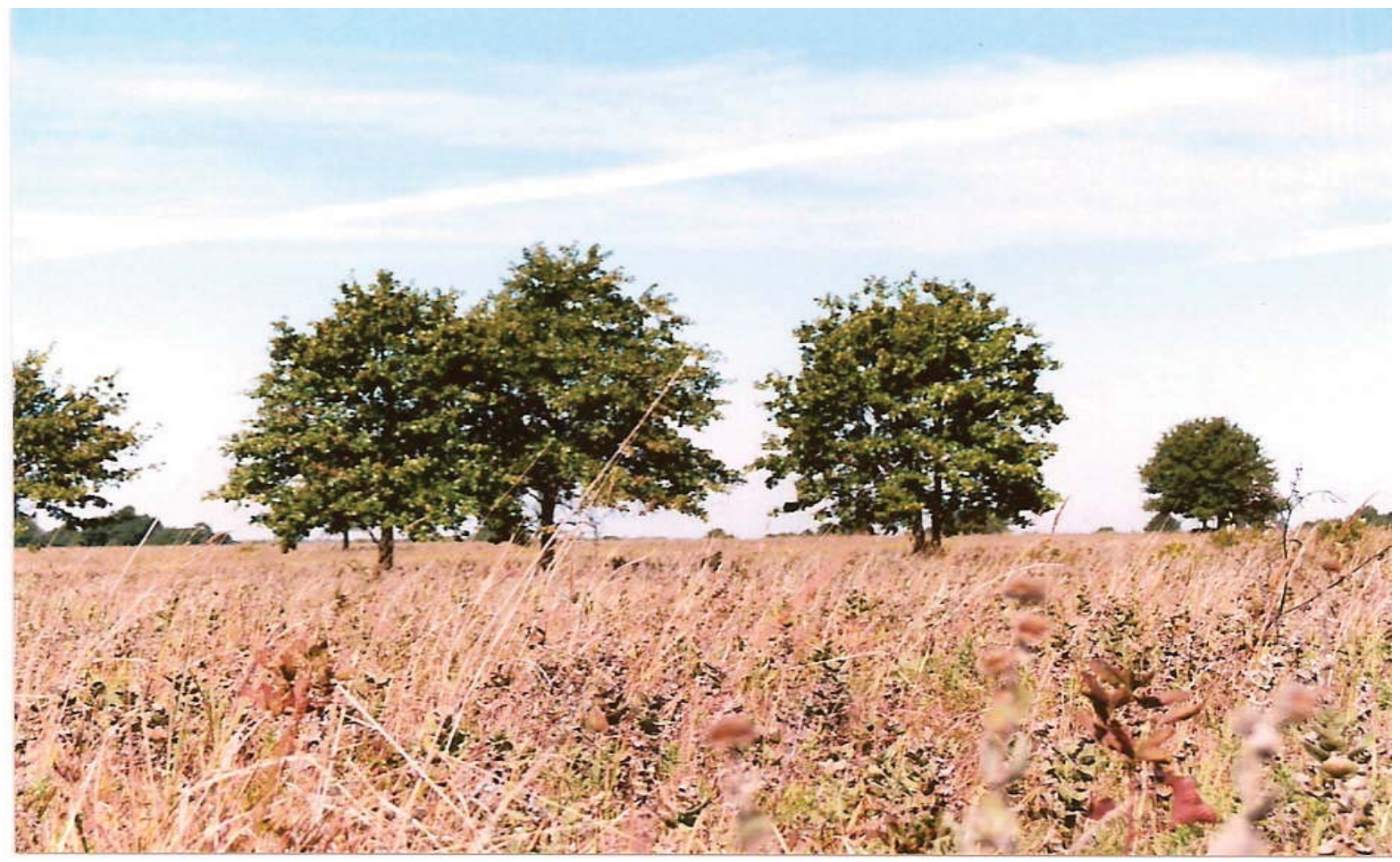

Figure 4 A Blackjack oak savanna. These scattered trees provide for habitat diversity.

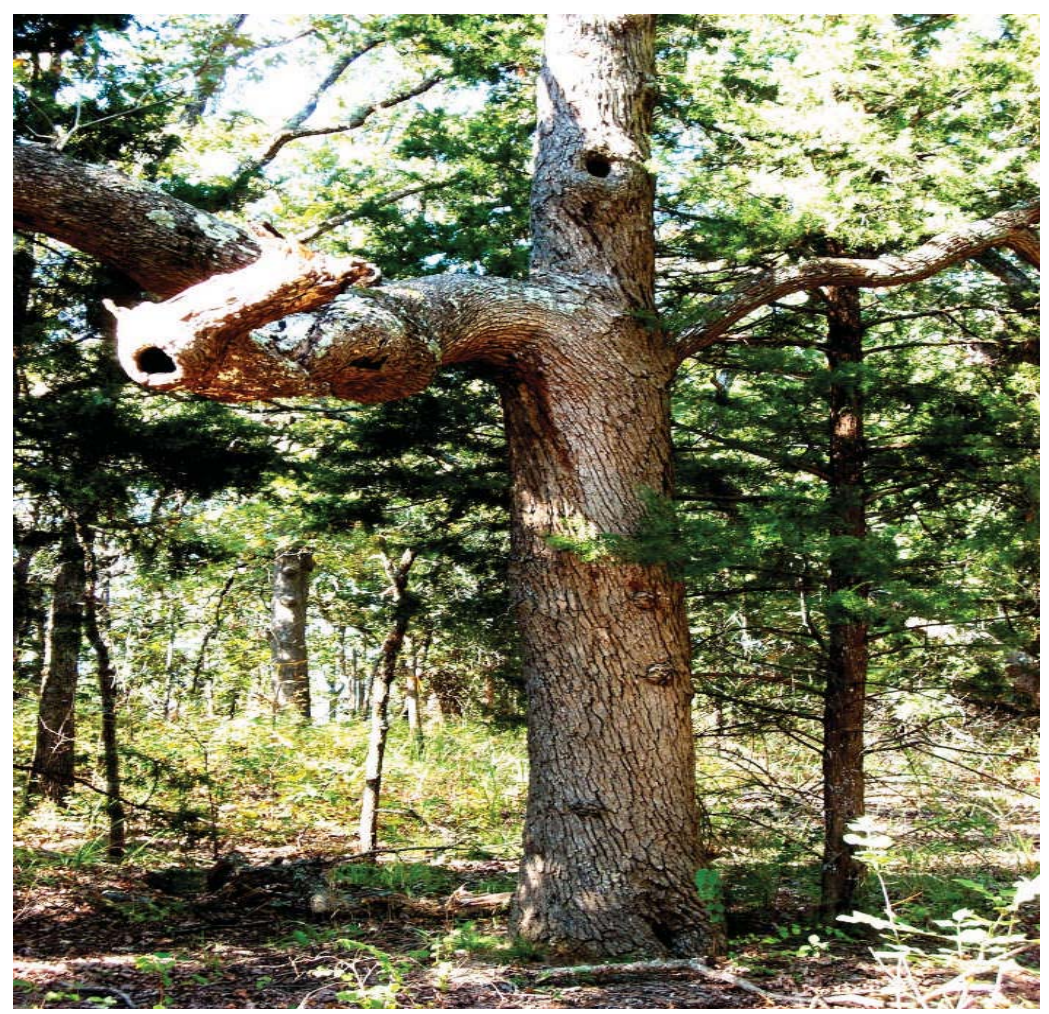

Figure 5 This old-growth post oak tree has low, horizontal branches. This type of architecture may be indicative of its having grown in an open-canopy environment. 
Oklahoma Native Plant Record

Volume 7, Number 1, December 2007

\section{RESTORATION RECOMMENDATIONS}

Restoration is the work of enhancing ecological quality. High quality communities have most natural processes intact and are rich in conservative plant species; those that are restricted to intact, natural remnants. Disrupted or degraded systems (those that have been plowed, overgrazed, protected from fire, etc.) lose those conservative species. The principal challenge in remnant restoration is to reinstate or speed up the processes that allow these remnantdependent species of plants and animals to regain their important roles in the system (Packard and Ross 1997).

Several authors have commented on the need for proactive land management to combat woody encroachment in the Cross Timbers (Dyksterhuis 1948, Smiens and Diamond 1986, Engle et al. 1996, 2006, Francaviglia 2000). Proactive land management practices are indeed recommended for restoring savanna. In degraded savannas, a combination of treatments is recommended for restoring an open-stand of trees with a grassy understory. Mechanical removal of trees with tree-clipping devices and/or chainsaws may be used to thin dense stands. For areas thick with shrubs, mowing treatments may be used. Fire should be used as a process to re-establish native grasses and forbs, with a long-term goal of promoting plant diversity and limiting woody encroachment.

There are many acres of private land in the Cross Timbers with degraded oak savanna. A major obstacle to restoring natural diversity on private lands has been the lack of economic incentive. Savanna restorations, however, may provide increased forage and combat further loss of forage due to woody encroachment. Light to moderate grazing can be compatible with maintaining the plant structure needed by many savanna species (Henderson 1995).
In addition to providing optimum habitat for many plant and wildlife species, oak savanna was probably the optimum habitat for many game species (e.g., bobwhite quail, turkey, deer, and rabbits) (Henderson 1995). Thus, management for oak savanna is compatible with traditional wildlife management and hunter interests.

The ultimate goal should be to help restore habitats, the loss of which, has lead to the gradual disappearance of plant and animal species (Packard 1988). For example, the black-capped vireo is a native to the Cross Timbers region. This federally endangered species prefers to nest in open savanna vegetation, and the decrease in open savanna vegetation has had negative impacts on the population (Hoagland et al. 1999). This is a prime example of how savanna restoration efforts could increase biodiversity by providing habitat for a target species.

Currently, savannas are not well represented throughout the Cross Timbers. Much of the Cross Timbers vegetation is now characterized by a mosaic of prairie and closed canopy forest. By restoring savanna communities, the structural diversity of the landscape is increased. These efforts will likely lead to higher compositional and functional diversity.

Mendelson et al. (1992), however, criticize what they believe is a rush to create savannas on forested sites that never supported savannas. Most crucially for the Cross Timbers, there are old-growth forests in the region that have never been savannalike. Such forests are clearly not a target for savanna restoration.

Careful research should be used to plan and implement any particular savanna restoration project (see Packard and Mutel 1997). Managers need to understand the characteristics of the site and the potential impacts of restoration techniques. Analysis of the site's existing plant communities and 
Oklahoma Native Plant Record

Volume 7, Number 1, December 2007

rare plant or animal populations is crucial. Inference of pre-settlement vegetation through analysis of Government Land Office (GLO) surveys, soils, and topography should help guide the process.

\section{ENVIRONMENTAL FACTORS INFLUENCING CROSS TIMBERS SAVANNAS}

Savanna represents one component of a complex and dynamic ecosystem. Within the Cross Timbers, there are several interacting environmental factors influencing vegetation for a given area. These include 1) climate; 2) soil; 3) topography; 4) grazing; and 5) fire. Understanding how all of these factors influence the relative abundance of woody and herbaceous plants is fundamental to managing for and restoring native savanna communities (McPherson 1997).

\section{Climate}

The Cross Timbers is home to a dynamic climate that is capable of supporting grassland or forest. There have been long-term 'dry' and 'moist' events, punctuated with shorter-term cyclic variations in climatic conditions (Dean et al.1984). The climate of the Cross Timbers has varied substantially even over the last few centuries, where changes in rainfall patterns have caused east-west shifts in the ecotone (Shaw and Lee 1995). Interannual and decadal variability in precipitation and temperature have been naturally high at both local and regional scales (McPherson 1997).

As precipitation regimes shifted, so did community composition and structure (Wright 1963). Extreme climatic events may be more important than shifts in means (Katz and Brown 1992) for changes in Cross Timbers savannas. "Pulses" of tree recruitment may occur during relatively brief periods of high soil moisture (McPherson 1997). Wet fuels decrease the likelihood of fire and allow for trees to take advantage of the higher soil moisture.

Subsequent growth of woody plants, may transform prairie into savanna or savanna into forest (Jameson 1987). On the other hand, the fine fuels which accumulate during these periods of high precipitation may also dispose the system to intense fire and thereby limit tree recruitment (Scholes and Archer 1997).

Significant destruction of Cross Timbers trees during long periods of drought have been documented (Rice and Penfound 1959). While grasses are also damaged by drought, they may rapidly reestablish areas due to their propagation by rhizomes once there is sufficient soil moisture (Weaver 1968). Major droughts in the Cross Timbers region occur at unpredictable intervals. Such droughts may increase the chance of fire due to dry fuels (Axelrod 1985), however, it may decrease fire intensity due to decreased fuel production (Skarpe 1992).

Due to the effects of a variable precipitation and fire regime, Cross Timbers savannas have possibly experienced a high degree of shifting on the landscape, as well as conversions to full prairie or forest. Present vegetation may represent one phase of a continually changing assembly of communities (Wethington 1994). This information is important for predicting how a natural savanna community might respond to changes in climate.

\section{Soils}

The very existence of Cross Timbers trees is largely traceable to certain geologic units from which the sandy soils are derived (Dyksterhuis 1948). These alternating materials have formed different soil associations that are characterized by coarse-textured sandy loam soils and by fine-textured clay loam soils. These are generally associated with savanna or forest, and grassland respectively (Dyksterhuis 1948, Smeins and Diamond 1986). 
Oklahoma Native Plant Record

Volume 7, Number 1, December 2007

Studies in the Cross Timbers have indicated that soil moisture availability is the primary factor controlling species composition (Clark 2003, Johnson and Risser 1972, Rice and Penfound 1959). The higher moisture-retaining capacity of coarsetextured soils is largely responsible for supporting the higher water demands of trees where rainfall is marginal for tree survival (Bell and Hulbert 1974). Finetextured soils may reduce water availability to woody plants below thresholds necessary for survival in the dry summers (McAuliffe 1994).

The USDA (2007) characterizes certain soil types in the Cross Timbers as 'savanna' range site. These are the most likely locations in which to restore a degraded savanna.

\section{Topography}

Topography influences the 'fire probability pattern' (Grimm (1984) that results from frequent fires superimposed on landscape features that include fire-prone topographic regions as well as natural fire barriers. Frequency of fires for a prairieforest ecotone in pre-settlement times was largely determined by topographic relief and the distribution of firebreaks, such as waterways (Anderson 1990).

Because fire frequency was determined by the roughness of landscape features, the density of trees on a landscape can often be viewed as a function of surface roughness (Anderson 1990). Old-growth forest in the Cross Timbers is highly related to steep and rocky slopes (Therrell and Stahle 1998). Much of the Cross Timbers forest prior to settlement was likely associated with a fire-protected landscape. As previously mentioned, old growth forests are not the place for savanna restoration.

\section{Grazing}

Native herbivores influenced the proportion of woody and herbaceous plants by disproportionately consuming or damaging more of one vegetation type than the other (McPherson 1997). As such, herbivores may interact with competition patterns between woody and herbaceous vegetation as well as with fire regimes, and may thus be involved in large-scale physiognomic dynamics of savannas (Skarpe 1991).

Ungulates like bison, elk, deer and pronghorn antelope, among other herbivores were all present on the historical prairie/forest transition. Of these, bison may have had the greatest impact on woody plant establishment in terms of their huge numbers and their alteration of fire intensity (Shaw and Lee 1995).

High grass biomass can affect tree biomass by fueling fires. Bison grazing could have reduced the fuel load and reduced fire frequency, intensity, or continuity of spread (Baisan and Swetham 1990). However, bison herds are believed to have existed in low numbers in the Cross Timbers (Shaw and Lee 1995).

The effects of overgrazing cattle likely differed drastically from historical bison grazing in the Cross Timbers. In the absence of heavy cattle grazing, a considerable quantity of litter was produced between established trees. When fires started with these heavy fuel loadings, small trees and saplings were knocked back. The result was an open stand of timber (Penfound 1962). In managing for savanna communities, overgrazing should not be allowed to reduce the fuel loading to the point where fire cannot suppress woody plants.

\section{Fire}

Fire has influenced plant communities for millions of years. Fires are thought to be important for the origin and maintenance of grassland, savanna, and woodland community physiognomies by limiting woody plant establishment (Anderson 1990, Sullivan 1995, Dorney and Dorney 1989).

Native Americans have been in the Southern Plains for more than 10,000 years 
Oklahoma Native Plant Record

Volume 7, Number 1, December 2007

(Kay 1998), during which they set frequent fire to the tallgrass prairie landscape (Shaw and Lee 1995, Moore 1995).

Fire may promote grasses or woody plants in Cross Timbers savannas, as both vegetation types are well-adapted to fire. Fire frequency, fire intensity, and fire season interact to shape the response of vegetation to fire (Wright and Bailey 1982, Engle et al. 1996). A given fire may favor either grasses or trees depending on the nature of these interactions.

The frequency of fire plays a critical role. In savanna ecosystems, a decrease in fire frequency leads to woody encroachment, while more frequent fires may favor a relatively stable community (Scholes and Archer 1997). Frequent fires, however, do little to suppress woody plant development if they are of low intensity (Briggs et al. 2005).

Fire intensity varies as a function of weather, stage of plant development, fuel load, topography, soil type, and previous management (Bidwell et al. 2004). Generally, a well managed rangeland with plenty of fine fuels will produce a high intensity fire that may effectively control woody plant establishment. This underscores the importance of the current vegetation in not only shaping the fire environment, but also in the response of vegetation to a given fire (Engle et al. 1996).

The season of a fire is very important for the relative effect on grasses and woody plants. The way species respond to a fire depends heavily on the timing of the fire relative to their phenological development. In general, plants that are actively growing, flowering, or setting seed at the time of the fire, tend to decline over time (Davidson and Kindscher 1999). Burning at different times of the year is recommended to inhibit certain species from dominating the community and to promote biodiversity. To control woody plants, burning following bud break and full leaf-out is the most effective time (Bidwell et al. 2004).
Once a savanna is re-established, carefully prescribed burns can maintain open stands of Cross Timbers oaks for long periods of time (Engle et al. 2006). Used wisely, prescribed fire can enhance biodiversity, combat tree encroachment, reduce danger of catastrophic wildfires, and improve range conditions for livestock.

\section{RESEARCH NEEDS}

The current extent of high-quality savanna stands should be assessed throughout the Cross Timbers. Judgments must be made as to the degree to which stands of vegetation appear to be functioning under natural ecological processes. Plant identification in highquality stands of oak savanna should be used to provide information on flora composition, richness and physiognomy. Lists of fauna that utilize and prefer these communities should be compiled. This information can be used to assess the integrity and functions of savanna communities, to analyze their contribution to the biodiversity of the Cross Timbers, and as reference information for restoration efforts.

While numerous studies indicate that savannas were important components of the historic Cross Timbers, their actual extent is uncertain. Assessing the actual past extent of savanna remains a top research priority. If savanna historically dominated the Cross Timbers region and are now very poorly represented, their conservation would be a very high priority. If savannas were originally rare and transient, they would deserve less attention than if they are the last remnant of a vast vegetation type. Unfortunately, tools for assessing past extent of savanna vegetation are limited.

GLO surveys are perhaps the best available tool. Early land survey records have contributed significantly to our understanding of the structure of North America's pre-settlement ecosystems. By

Stotts, et al. 
Oklahoma Native Plant Record

Volume 7, Number 1, December 2007

way of summary, land surveys have been used to determine: 1) species compositions of pre-settlement savannas and woodlands; 2) landscape-level disturbance processes; 3) site-specific determinants; 4) species associations and community classification, and; 5) vegetation types for mapping purposes (Egan and Howell 2005).

This information has figured prominently in the restoration of a number of historic ecosystems (Egan and Howell 2005). Schroeder (1981), for instance, created a statewide map of GLO surveys from Missouri that described a mosaic of forest, woodland, savanna, and prairie landscapes. The map serves as a foundation for the Missouri Department of Natural Resources efforts to restore savanna ecosystems in that state's parks (McCarty 1998). This information is commonly used as a reference for restoration efforts, and numerous post oak savanna restorations have occurred with success in Missouri.

The plat maps used for mapping, however, were made up solely on the basis of data written in the early surveyor's notes, which have certain biases and limitations (King 1978). Furthermore, we should view this information as but one snapshot of past vegetation patterns that were constantly shifting with an ever-changing climate, Native American activities (Batek et al. 1999), and grazing patterns. Also, early settlers may have cut down trees before the survey was completed. As such, we are forced to consider just how representative they are as a true picture of the "presettlement" vegetation (Noss 1985).

The dynamics of savannas are not well known because landscape-level processes have been radically, and sometimes irreversibly altered by recent human activities. (Rebertus and Burns 1997) Further research should increase our understanding of the mechanisms of the Cross Timbers ecosystem. Elucidation of the interactions, dynamics and determinants, and identification of robust generalizations that can be broadly applied to savanna ecosystems would benefit ecological theory, modeling and land management (House et al. 2003). Fundamental questions include: What controls the relative abundance of woody and herbaceous plants for a given set of conditions at given site? How do the vegetation types interact with each other? Is a given woody-herbaceous ratio dynamically stable and persistent under a particular set of conditions (House et al. 2003).

Finally, circumstances under which restoration techniques are effective or ineffective need to be identified. As such, restoration efforts should be monitored.

\section{CONCLUSION}

Oak savannas throughout the Cross Timbers region have been degraded by woody encroachment. Savanna restoration efforts are recommended to combat this threat to biodiversity. The ultimate goal is to restore ecological processes and help replace lost habitat that is leading to the gradual disappearance of plant and animal species. There is, however, much that is unknown about the ecological dynamics and functions of savanna communities. It is hoped that with research and restoration of savanna communities, some answers will be provided.

\section{ACKNOWLEDGMENTS}

The authors recognize the invaluable contributions of the following: The Stotts family, Jim Minnerath, Daniel Dyer, the USFWS Eastern Kansas District Fire Crew, and the Stotts.

\section{LITERATURE CITED}

Abrams, M.D. 1992. Fire and the development of oak forests. BioScience 52: 346-353.

Anderson, R.C. 1990. The historic role of fire in the North American grassland. In: Collins, S. L. and L.L. Wallace. Fire in North American tallgrass prairies. 
Norman and London: University of Oklahoma Press. p 8-18.

Archer, S. 1995. Tree-grass dynamics in a Prosopis-thornscrub savanna parkland: reconstructing the past and predicting the future. Ecoscience 2: 83-99.

Axelrod, D.L. 1985. Rise of the grassland biome, Central North America. The Botanical Review 51: 163-201.

Batek, M.J. 1999. Reconstruction of early nineteenth-century vegetation and fire regimes in the Missouri Ozarks. Journal of Biogeography 26: 397-412.

Bell, E. and Hulbert, L. 1974. Effect of soil on occurrence of cross timbers and prairie in Southern Kansas. Transactions of the Kansas Academy of Science.

Baisan, C.H. and T.W. Swetnam. 1990. Fire history on a desert mountain range: Rincorn Mountain Wilderness, Arizona, USA. Canadian Journal of Forestry Restoration 20: 1559-1569.

Briggs, J.M., A.K. Knapp, J.M. Blair, J.L. Heisler, G.A. Hoch, M.S. Lett and J.K. McCarron. 2005. An ecosystem in transition: causes and consequences of the conversion of mesic grassland to shrubland. Bioscience 55: 243-254.

Bruner, W.E. 1931. The vegetation of Oklahoma. Ecological Monographs 1(2): 100-113.

Clark, S. L. 2003. Stand dynamics of an oldgrowth oak forest in the cross timbers of Oklahoma. [dissertation] Stillwater: Oklahoma State University. 193 pages.

Costello, D.F. 1969. The prairie world. University of Minnesota Press. Minneapolis, Minnesota. 244 pages.

Davison, C. and K. Kindscher. 1999. Tools for diversity: fire, grazing, and mowing on tallgrass prairies. Ecological Restoration 17: 136-143.

Dean, W.E., J.P. Bradburn, R.Y. Anderson, C.W. Barnosky. 1984. The variability of Holocene climate change: Evidence from varved lake sediments. Science 226: 1191 1194.

Dorney, C.H. and J.R. Dorney. 1989. An unusual oak savanna in Northeastern Wisconsin: the effect of Indian-caused fire. American Midland Naturalist 122: 103-113.
Dyksterhuis, E.J. 1948. The vegetation of the western cross timbers. Ecological Monographs 18: 325-376.

Dyksterhuis, E.J. 1957. The savannah concept and its use. Ecology 38: 435-442.

Egan, D. and E.A. Howell. 2005. The historical ecology handbook: A restorationist's guide to reference ecosystems. Society for Ecological Restoration International. Island Press. 457 pages.

Engle, D. M., T. N. Bodine and J. E. Stritzke (2006). Woody plant community in the cross timbers over two decades of brush treatments. Rangeland Ecology \& Management 59(2): 153-162.

Engle, D.M., T.G. Bidwell and R.E. Masters. 1996. Restoring cross timbers ecosystems with fire. Transactions 61 $1^{\text {st }}$ North American Wildlife and Natural Resource Conference. p 190-199.

Faber-Langendeon, D. 2001. Plant communities of the Midwest: classification in an ecological context. Association for Biodiversity Information, Arlington, Virginia, 2001. 61 pages.

Francaviglia, R. V. 2000. The cast iron forest: A natural and cultural history of the North American cross timbers. Austin, University of Texas Press.

Grimm, E.C. 1984. Fire and other factors controlling the Big Woods vegetation of Minnesota in the mid-19th century. Ecological Monographs 54: 291-311.

Henderson, R. 1995. Oak savanna communities. In Wisconsin's biodiversity as a management issue: A report to Department of Natural Resources Managers. Madison: Wisconsin Department of Natural Resources. p 88-96.

Hoagland, B. W., I. Butler, F.L. Johnson and S. Glen. 1999. The cross timbers. In R. C. Anderson, J. Fralish and J. Baskin. The savanna, barren and rock outcrop communities of North America. New York: Cambridge University Press. p 231-244.

House, J. I., S. Archer, D. D. Breshears and R. J. Scholes (2003). Conundrums in mixed woody-herbaceous plant systems. Journal of Biogeography 30(11): 1763-1777.

Jameson, D.A. 1987. Climax or alternative steady states in woodland ecology. In Everett, R.L. (ed). Proceedings: Pinyon- 
Oklahoma Native Plant Record

Volume 7, Number 1, December 2007

juniper conference, USDA For. Serv. Gen. Tech. Rep. INT-215, Ogden, UT. p 9-13.

Johnson, F.L. and P.G. Risser. 1972. Some vegetation-environment relationships in the upland forests of Oklahoma. Journal of Ecology 60: 655-663.

Johnson, F. L. and P. G. Risser 1975. A quantitative comparison between an oak forest and an oak savannah in central Oklahoma. Southwestern Naturalist 20: 7584.

Katz, R.W. and B.G. Brown. 1992. Extreme events in a changing climate: variability is more important than averages. Climatic Change 21: 289-302.

Kay, M. 1998. The central and southern plains archaic. Archeology on the Great Plains. University Press of Kansas. 522 pages.

Kline, V.M. 1997. Orchards of oak and a sea of grass. In Packard, S. and Cornelia F. Mutel (eds). The tallgrass restoration handbook: For prairies, savannas, and woodlands. Washington, D.C.; Island Press. p 3-21.

King, J.E. 1978. Late quarternary vegetational history of Illinois. Ecological Monographs 51: 43-62.

Küchler, A.W. 1964. Potential natural vegetation of the conterminous United States, American Geographical Society, Special Publication No. 36. p 586-604.

Küchler, A.W. 1974. A new vegetation map of Kansas. Ecology 55: 586-604.

Lathrop, E.W. 1958. The flora and ecology of the Chautaqua Hills in Kansas. University of Kansas Science Bulletin 39: 97-209.

Lauver, C.L., K. Kindscher, D. FaberLangendoen and R. Schneider. 1999. A classification of the natural vegetation of Kansas. The Southwestern Naturalist 44: 421-443.

McAuliffe, J.R. 1994. Landscape evolution, soil formation, and ecological patterns and processes in Sonoran Desert bajadas. Ecological Monographs 64: 111-148.

McCarty, K. 1998. Landscape-scale restoration in Missouri savannas and woodlands. Restoration \& Management Notes 16(1): 22-32.

McPherson, G.R. 1997. Ecology and management of North American savannas. Tucson: The University of Arizona Press.
Mendelson, J., S.P. Atultz, and J.D. Mendelson. 1992. Carving up the woods: Savanna restoration in northeastern Illinois. Restoration \& Management Notes. 10(2): 127-131.

Moore, C.T. 1972. Man and fire in the Central North American grassland 1535-1890: A documentary historical geography. [dissertation] Los Angeles: University of California..

Noss, R.F. 1985. On characterizing presettlement vegetation: how and why. Natural Areas Journal 5: 1-19.

Nuzzo, V.A. 1985. Extent and status of Midwest oak savanna: presettlement and 1985. The Natural Areas Journal 6: 6-36.

Oklahoma Biodiversity Task Force. 1996. Oklahoma's biodiversity plan: A shared vision for conserving our natural heritage. Oklahoma City: Oklahoma, Oklahoma Department of Wildlife Conservation.

Packard, S. 1988. Just a few oddball species: restoration and the rediscovery of the tallgrass savanna - in Cook County, Illinois. Restoration and Management Notes 6, no. 1: 13-20.

Packard, S. and C.F. Mutel. 1997. Perspective. The Tallgrass Restoration Handbook: For Prairies, Savannas, and Woodlands. Washington D.C. Island Press. p xxv- xxxiv.

Packard, S. and L.M. Ross. 1997. Restoring Remnants. In Packard, S. and Cornelia F. Mutel (eds). The Tallgrass Restoration Handbook: For Prairies, Savannas, and Woodlands. Washington D.C. Island Press. p 63-88.

Palmer, M. W. (in press). Vascular flora of the Tallgrass Prairie Preserve, Osage County, Oklahoma. Castanea. Forthcoming.

Palmer, M.W. and P.S. White. 1994. On the existence of ecological communities. Journal of Vegetation Science 5: 279-282.

Penfound, W. T. (1962). The savanna concept in Oklahoma. Ecology 43(4): 774-775.

Rebertus, A.J. and B.R. Burns. 1997. The importance of gap processes in the development and maintenance of oak savannas and dry forests. The Journal of Ecology 85: 635-645.

Rice, E.L. and W.T. Penfound. 1959. The upland forests of Oklahoma. Ecology 40: 593-608. 
Scholes, R.J. and S.R. Archer. 1997. Tree-grass interactions in savannas. Annual Review of Ecological Systems 28: 517-544.

Schroeder, S.A. 1981. Presettlement prairie of Missouri. Natural History Series, Publication No. 2. Jefferson City: Missouri Department of Conservation.

Shaw, J.H. and M. Lee. 1995. Ecological interpretation of historical accounts of bison and fire on the southern plains with emphasis on tallgrass prairie. A final report to the Nature Conservancy of Oklahoma. Oklahoma State University.

Skarpe, C. (1991). Impact of grazing in savanna ecosystems. Ambio 20: 351-356.

Skarpe, C. 1992. Dynamics of savanna ecosystems. Journal of Vegetation Science 3: 293-300.

Smeins, F.E. and D.D. Diamond. 1986. Grasslands and savannahs of East Central Texas: Ecology, preservation status and management problems. In Kulhavy, David L. and Richard N. Conner. 1986.

Wilderness and Natural Areas in the United States: A management challenge. p 381-394.

Sullivan, Janet. 1995. Oak-hickory forest. In Fire effects information system, U.S. Department of Agriculture, Forest Service, Rocky Mountain Research Station, Fire Science Laboratory.
Therrell, M.D. and D.W. Stahle. 1998. A predictive model to locate ancient forests in the Cross Timbers of Osage County, Oklahoma. Journal of Biogeography 25: 847-854

USDA, Agricultural Research Service, Southern Plains Range Research Station. 2007. Range Sites Short Course. [online]. Available: www.sprrs.usda.gov/range sites.htm (Accessed 2007 November 12).

Weaver, J.E. 1968. Prairie plants and their environment: A fifty-year study in the Midwest. University of Nebraska Press. Lincoln and London.

Wethington, M. K. 1994. A spatial and temporal analysis of forest and grassland changes at the tallgrass prairie preserve [M.S. thesis]. Stillwater: Oklahoma State University.

Whitney, G.G. and Decant, J.P. 2005. Government Land Office Surveys and Other Early Land Surveys. The Historical Ecology Handbook. Washington D.C.: Island Press. p 147-172.

Wright, Jr., H.E. 1963. Vegetational history of the Central Plains. Pleistocene and recent environments of the Central Great Plains. Lawrence, Kansas: Department of Geology, University of Kansas.

Wright, H.A. and A.W. Bailey. 1982. Fire ecology. John Wiley and Sons, New York, N.Y. 